\title{
KAJIAN KUALITAS UMBI UBI JALAR SEBAGAI SUBSTITUSI SUSU SKIM \\ DALAM PEMBUATAN ES KRIM
}

\author{
Rekna Wahyuni \\ Universitas Yudharta Pasuruan
}

\begin{abstract}
ABSTRAK: Teknologi pengolahan pangan modern telah menghasilkan kreasi baru olahan ubi jalar, salah satunya adalah es krim ubi jalar. Es krim adalah produk pangan beku yang biasa dikonsumsi sebagai makanan selingan (desert) dengan bahan-bahan utama dalam pembuatannya seperti lemak, bahan kering tanpa lemak (BKTL) atau padatan bukan lemak, bahan pemanis, bahan penstabil, dan bahan pengemulsi. Penelitian untuk melihat pengaruh subtitusi susu skim dengan ubi jalar sebagai sumber padatan bukan lemak terhadap tingkat kesukaan (preferensi) panelis telah dilakukan di Laboratorium Teknologi Pertanian Universitas Yudharta Pasuruan pada bulan April sampai Mei 2008. Perlakuan yang digunakan adalah perbandingan penggunaan susu skim dan ubi jalar, yaitu sebagai berikut : (1) susu skim : ubi jalar $=0 \%: 10 \%$; (2) susu skim : ubi jalar $=2,5 \%: 7,5 \%$; (3) susu skim : ubi jalar $=5 \%: 5 \%$; (4) susu skim : ubi jalar $=7,5 \%: 2,5 \%$; dan (5) susu skim : ubi jalar $=$ 10\% : $0 \%$ (= kontrol). Analisis yang digunakan adalah analisis organoleptik berupa uji hedonik. Analisis dilakukan di Laboratorium Teknologi Pertanian Universitas Yudharta Pasuruan, dengan menggunakan 15 panelis semi terlatih yang sekaligus dipakai sebagai ulangan. Selain itu, juga dilakukan pengamatan terhadap over run es krim dan kecepatan meleleh di suhu ruang. Hasil analisis menunjukkan bahwa subtitusi susu skim dengan umbi ubi jalar kukus sebagai padatan bukan lemak dalam pembuatan es krim dapat diterima oleh panelis. Es krim dengan perbandingan susu skim dan ubi jalar 7,5\%:2,5\% memiliki mutu yang baik, dari segi organoleptik, over run, dan kecepatan meleleh.
\end{abstract}

Kata kunci : es krim ubi jalar, uji hedonik, over run, kecepatan meleleh

\section{PENDAHULUAN}

Tanaman ubi jalar (Ipomea batatas) berasal dari Amerika bagian Tengah dan pada sekitar tahun 1960an ubi jalar telah menyebar dan ditanam di hampir seluruh wilayah Indonesia (Rukmana, H. R, 2001). Karakteristik umbi ubi jalar atau sweet potato adalah warna kulit antara jingga muda, jingga sampai cokelat muda, warna daging umbi jingga muda, jingga sampai kuning, dan rasa umbi manis, manis agak berair, manis berair sampai manis enak tergantung pada varietasnya. Beberapa varietas ubi jalar adalah seperti Daya, Prambanan, Borobudur, Mendut, dan Kalasan.

Di tiap daerah di Indonesia, selalu ada varietas lokal ubi jalar dimana rata-rata tiap varietas memiliki karakteristik yang berbeda dengan keunggulan tertentu, seperti 
Ubi Selat Jawa Timur yang warna dagingnya dominan ungu dengan selingan cokelat-jingga dan terkenal sebagai bahan pembuatan keripik, Ubi Gunung Kawi yang jika dikukus warna kulit umbi akan mengkilap dan rasanya sangat manis, Ubi Madu Cilembu yang istimewa karena umbinya yang dipanggang mengeluarkan cairan kental dengan rasa yang sangat manis, Ubi Bali yang sering disajikan sebagai pendamping buah-buahan dalam pembuatan rujak manis, Ubi Papua yang diduga merupkan indukan dari varietas ubi jepang, dan Ubi Jepang yang cukup populer di Indonesia dengan berbagai varietas seperti ibaraki, beniazuma, dan naruto (Hartoyo, T, 2004). Secara umum kandungan gizi umbi ubi jalar seperti dapat dilihat pada Tabel 1.

Tabel 1. Komposisi Kimia Ubi Jalar

\begin{tabular}{|l|c|}
\hline \multicolumn{1}{|c|}{ Kandungan } & Komposisi \\
\hline \hline Energi (KJ/100 g) & 71,1 \\
\hline Protein (\%) & 1,43 \\
\hline Lemak (\%) & 0,17 \\
\hline Pati $(\%)$ & 22,4 \\
\hline Gula $(\%)$ & 2,4 \\
\hline Serat makanan $(\%)$ & 1,6 \\
\hline Kalsium $(\mathrm{mg} / 100 \mathrm{~g})$ & 29 \\
\hline Fosfor $(\mathrm{mg} / 100 \mathrm{~g})$ & 51 \\
\hline Besi $(\mathrm{mg} / 100 \mathrm{~g})$ & 0,49 \\
\hline Vitamin A $(\mathrm{mg} / 100 \mathrm{~g})$ & 0,01 \\
\hline Vitamin B1 $(\mathrm{mg} / 100 \mathrm{~g})$ & 0,09 \\
\hline Vitamin C $(\mathrm{mg} / 100 \mathrm{~g})$ & 24 \\
\hline Air $(\mathrm{g})$ & 83,3 \\
\hline \hline
\end{tabular}

Sumber : Hendroatmojo (1990) dalam Hartoyo, $T$ (2004)

Berat kering umbi adalah $16-40 \%$ berat basah. Potensi besar ubi jalar terutama terletak pada kandungan karbohidrat, dimana sebanyak $75-90 \%$ berat kering umbi merupakan gabungan dari pati, gula, dan serat seperti selulosa, hemiselulosa, dan pektin (Hartoyo, T, 2004). Karbohidrat di dalam umbi ini telah banyak diolah lebih lanjut. Teknik olahan tradisional yang sudah banyak diterapkan di masyarakat dalam bentuk beberapa jajanan lokal, seperti kue apem, kue mangkok, dan pilus dari ubi jalar, termasuk juga keripik ubi jalar. Teknologi pengolahan pangan modern juga telah banyak berperan menghasilkan kreasi baru olahan ubi jalar, dengan bentuk yang paling banyak berupa jajanan atau makanan ringan (snack food). Dalam pembuatan makanan ini, ubi jalar dapat berperan sebagai bahan utama atau bahan pensubtitusi. Salah satu jenis makanan yang memanfaatkan 
umbi ubi jalar sebagai bahan bakunya adalah es krim.

Es krim adalah produk pangan beku yang dibuat melalui kombinasi proses pembekuan dan agitasi pada bahan-bahan yang terdiri dari susu dan produk susu, pemanis, penstabil, pengemulsi, serta penambah citarasa (flavor). Es krim biasa dikonsumsi sebagai makanan selingan (desert) dan dikelompokkan dalam makanan camilan (snack). Prinsip pembuatan es krim adalah membentuk rongga udara pada campuran bahan es krim atau Ice Cream Mix (ICM) sehingga diperoleh pengembangan volume yang membuat es krim menjadi lebih ringan, tidak terlalu padat, dan mempunyai tekstur yang lembut (Padaga, M, dkk, 2005).

Syarat mutu es krim menurut SII (Standar Industri Indonesia) Nomor 1617 Tahun 1985 dalam Padaga, M, dkk (2005) adalah sebagai berikut :

\begin{tabular}{lll}
\hline \multicolumn{1}{c}{ Bahan } & Standar \\
\hline Lemak (\%) & $:$ & Minimal 8,0 \\
Padatan susu bukan lemak (\%) & $:$ & Minimal 6,0-15,0 \\
Gula (\%) & $:$ & Minimal 12,0 \\
Bahan Tambahan : & $:$ & Sesuai SK Depkes RI No. \\
Pemantap, pengemulsi & $:$ & 235/Menkes/Per/VI/79 \\
Zat warna & $:$ & \\
Pemanis buatan & $:$ & Negatif \\
Jumlah bakteri & & \\
Logam-logam berbahaya : & $:$ & Tidak terdapat \\
Cu, Zn, Pb, Hg & $:$ & Tidak terdapat \\
Arsen & & \\
\hline
\end{tabular}

Bahan-bahan utama yang diperlukan dalam pembuatan es krim antara lain : lemak, bahan kering tanpa lemak (BKTL), bahan pemanis, bahan penstabil, dan bahan pengemulsi. Lemak susu (krim) merupakan sumber lemak yang paling baik untuk mendapatkan es krim berkualitas baik. Lemak susu berfungsi untuk meningkatkan nilai gizi es krim, menambah citarasa, menghasilkan karakteristik tekstur yang lembut, membantu memberikan bentuk dan kepadatan, serta memberikan sifat meleleh yang baik. Bahan kering tanpa lemak
(BKTL) berfungsi untuk meningkatkan kandungan padatan di dalam es krim sehingga lebih kental. BKTL juga penting sebagai sumber protein sehingga dapat meningkatkan nilai nutrisi es krim. Unsur protein dalam pembuatan es krim berfungsi untuk menstabilkan emulsi lemak setelah proses homogenisasi, menambah citarasa, membantu pembuihan, meningkatkan dan menstabilkan daya ikat air yang berpengaruh pada kekentalan dan tekstur es krim yang lembut; juga dapat meningkatkan nilai over run es krim. Sumber BKTL antara lain susu skim, susu 
kental manis, dan bubuk whey (Padaga, M, dkk, 2005).

Bahan pemanis yang umum digunakan dalam pembuatan es krim adalah gula pasir (sukrosa) dan gula bit. Bahan pemanis selain berfungsi memberikan rasa manis, juga dapat meningkatkan citarasa, menurunkan titik beku yang dapat membentuk kristal-kristal es krim yang halus sehingga meningkatkan penerimaan dan kesukaan konsumen. Penambahan bahan pemanis sekitar 12 sampai 16 gram per 100 gram campuran es krim akan menghasilkan es krim dengan tekstur yang halus. Laktosa (gula dari susu) juga merupakan sumber pemanis selain gula yang ditambahkan dari luar. Laktosa berfungsi untuk menahan titik beku sehingga es krim masih mengandung air yang tidak membeku jika disimpan pada temperatur yang sangat rendah $(-15$ sampai $\left.-18^{\circ} \mathrm{C}\right)$. Jika seluruh air di dalam es krim membeku selama penyimpanan, tekstur es krim akan menjadi keras dan sulit disendok (Padaga, M, dkk, 2005).

Bahan penstabil yang umum digunakan dalam pembuatan es krim adalah CMC (carboxy methyl celulose), gum arab, sodium alginat, karagenan, dan agar. Bahan penstabil berperan untuk meningkatkan kekentalan ICM terutama pada saat sebelum dibekukan dan memperpanjang masa simpan es krim karena dapat mencegah kristalisasi es selama penyimpanan. Bahan pengemulsi utama yang digunakan dalam pembuatan es krim adalah kuning telur, juga minyak hewan atau nabati.Bahan pengemulsi bertujuan untuk memperbaiki struktur lemak dan distribusi udara dalam ICM, meningkatkan kekompakan bahanbahan dalam ICM sehingga diperoleh es krim yang lembut, dan meningkatkan ketahanan es krim terhadap pelelehan bahan. Campuran bahan pengemulsi dan penstabil akan menghasilkan es krim dengan tekstur yang lembut (Padaga, M, dkk, 2005).

Es krim yang baik harus memenuhi persyaratan komposisi umum ICM (Ice Cream Mix) atau campuran es krim sebagai berikut :

\begin{tabular}{|l|l|}
\hline Lemak susu & $: 10-16 \%$ \\
\hline Bahan kering tanpa lemak & $: 9-12 \%$ \\
\hline Bahan pemanis gula & $: 12-16 \%$ \\
\hline Bahan penstabil & $: 0-0,4 \%$ \\
\hline Bahan pengemulsi & $: 0-0,25 \%$ \\
\hline Air & $: 55-64 \%$ \\
\hline
\end{tabular}

Sumber: Padaga, M, dkk (2005) 
Proses pembuatan es krim dimulai dengan pencampuran bahanbahan yang dilakukan dengan cara melarutkan atau mencampurkan bahan-bahan kering ke dalam bahan cair pada kondisi hangat $\left(40^{\circ} \mathrm{C}\right)$, lalu sambil dipanaskan dimasukkan bahan penstabil dan bahan pengemulsi sampai diperoleh campuran homogen yang disebut ICM. Campuran kemudian dipasteurisasi pada suhu $80^{\circ} \mathrm{C}$ selama 25 detik, sambil terus diaduk. Pasteurisasi bertujuan untuk membunuh mikroorganisme patogen, melarutkan bahan kering, dan meningkatkan citarasa. Selanjutnya ICM didinginkan sampai suhu ruang untuk dihomogenisasi dengan tujuan memecah globula lemak sehingga ukurannya lebih kecil dan dapat menyebar rata sehingga dihasilkan es krim dengan tekstur yang tidak kasar, mempunyai citarasa yang merata, dan daya buih yang baik. Homogenisasi pada pembuatan es krim skala rumah tangga dapat menggunakan blender atau mixer. Homogenisasi sebaiknya dilakukan saat kondisi ICM masih hangat (Padaga, M, dkk, 2005).

ICM kemudian di-aging, yang merupakan proses pematangan ICM dalam refrigerator bersuhu $4^{\circ} \mathrm{C}$ selama 4-12 jam. Tujuan aging adalah untuk menghasilkan ICM yang lebih kental, lebih halus, tampak lebih mengkilap, dan memperbaiki tekstur. Setelah proses aging, dilakukan proses homogenisasi kembali. Selanjutnya ICM dibekukan dengan cepat untuk mencegah terbentuknya kristal es yang kasar. Pembekuan dilakukan dalam dua tahap, yaitu tahap pertama pada suhu -5 sampai $-8^{\circ} \mathrm{C}$ dan tahap kedua pada suhu sampai $30^{\circ} \mathrm{C}$. Proses pembekuan yang dikombinasi dengan proses agitasi bertujuan untuk memasukkan udara ke dalam ICM sehingga dihasilkan volume es krim dengan over run yang sesuai standar es krim. Dalam skala rumah tangga, proses agitasi dapat dilakukan dengan menggunakan mixer berulang-ulang diselingi dengan proses pembekuan di dalam freezer. Setelah itu, es krim dapat dikemas dalah wadah-wadah kecil dan disimpan dalam freezer untuk proses pembekuan. Kualitas es krim akan tetap stabil pada suhu penyimpanan -25 sampai $-30^{\circ} \mathrm{C}$ (Padaga, M, dkk, 2005).

Tujuan penelitian ini adalah untuk melihat pengaruh subtitusi susu skim dengan ubi jalar sebagai sumber padatan bukan lemak terhadap tingkat kesukaan (preferensi) panelis.

\section{BAHAN DAN METODE}

\section{Waktu dan tempat}

Penelitian dilaksanakan di Laboratorium Teknologi Pertanian Universitas Yudharta Pasuruan dan Laboratorium THP UMM Malang pada bulan April sampai Mei 2008 


\section{Alat dan bahan}

Bahan yang digunakan dalam penelitian adalah ubi jalar varietas lokal dengan warna daging umbi kuning-orange, susu bubuk skim, susu bubuk full krim, whipped cream, gula pasir, telur, agar-agar, garam, dan air. Sementara, alat yang digunakan dalam penelitian adalah pisau, timbangan, panci pengukus, kompor gas, blender, mixer, panci, sendok pengaduk, thermometer, dan lemari pendingin (dengan refrigerator dan freezer).

Formulasi bahan yang digunakan dalam pembuatan es krim ubi jalar ini mengacu pada Padaga, M, dkk (2005), yaitu sebagai berikut : padatan lemak $10 \%$ berupa susu bubuk full krim dan whipped cream, padatan bukan lemak $10 \%$ berupa susu bubuk skim dan umbi ubi jalar, bahan pemanis $15 \%$ berupa gula pasir, bahan penstabil $0,5 \%$ berupa agar-agar dan putih telur, bahan pengemulsi berupa kuning telur, garam sebagai pengikat air, dan air.

\section{Metode pembuatan}

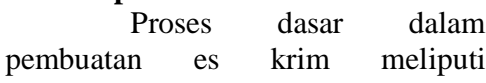
beberapa tahap, yaitu pencampuran bahan, pasteurisasi, homogenisasi, pematangan (aging), pembekuan dan agitasi, pengemasan, pembekuan, dan penyimpanan (Padaga, M, dkk, 2005).

Proses pembuatan es krim yang dilakukan dalam penelitian adalah sebagai berikut : (1) Umbi dicuci, dikukus, lalu dikupas; (2)
Dihaluskan; (3) Kuning telur dikocok sampai mengembang; (4) Bahan-bahan kering dimasukkan ke dalam air hangat sambil diaduk; (5) Campuran dipanaskan, sambil kuning telur, putih telur, dan agaragar dimasukkan dan terus diaduk; (6) Dipasteurisasi pada suhu 80$85^{\circ} \mathrm{C}$ selama 25 detik; (7) Adonan diangkat, didinginkan sampai suamsuam kuku, kemudian dihomogenisasi selama 15 menit; (8) Adonan disimpan di dalam refrigerator selama 4 jam untuk proses aging; (9) Dihomogenisasi ulang selama 15 menit; (10) Adonan disimpan di dalam freezer sampai setengah beku lalu diagitasi selama 15 menit; (11) Dikemas dalam wadah-wadah kemudian disimpan kembali ke dalam freezer.

\section{Metode analisis}

Perlakuan yang digunakan dalam penelitian adalah perbandingan penggunaan susu skim dan ubi jalar sebagai padatan bukan lemak, yaitu sebagai berikut : susu skim : ubi jalar $=0 \%: 10 \%$ (kode $801)$, susu skim : ubi jalar $=2,5 \%$ : 7,5\% (kode 675), susu skim : ubi jalar $=5 \%: 5 \%($ kode 305$)$, susu skim : ubi jalar $=7,5 \%: 2,5 \%$ (kode 725), dan susu skim : ubi jalar = 10\% : 0\% (= kontrol, kode 400).

Perbandingan penggunaan susu skim dan ubi jalar di atas adalah perbandingan untuk berat kering; sementara dalam penelitian digunakan umbi ubi jalar yang dikukus (berat basah) sehingga 
digunakan asumsi bahwa berat basah ubi jalar adalah sekitar 4 kali berat keringnya (berdasarkan Hartoyo, T (2004), dimana berat kering umbi adalah $16-40 \%$ berat basah atau ratarata sekitar $28 \%$ ).

Analisis yang dilakukan adalah analisis organoleptik berupa uji hedonik (skala 1-sangat tidak suka sampai 7-sangat suka) untuk melihat tingkat kesukaan (preferensi) panelis terhadap produk es krim ubi jalar. Analisis dilakukan di Laboratorium Pangan, Fakultas Pertanian, Universitas Yudharta Pasuruan, dengan menggunakan 15 panelis semi terlatih yang sekaligus dipakai sebagai ulangan. Selain itu, juga dilakukan pengamatan terhadap over run es krim dan kecepatan meleleh di suhu ruang. Over run dihitung dalam bentuk persentase over run berdasarkan perbedaan volume es krim dan ICM (=Ice Cream Mix) atau campuran es krim; sementara kecepatan meleleh dinyatakan dalam menit untuk melihat ketahanan es krim terhadap pelelehan pada saat dihidangkan di suhu ruang.

$\%$ Over run $=($ Volume es krim Volume ICM)/ Volume ICM * $100 \%$

\section{HASIL DAN PEMBAHASAN}

\section{Uji Hedonik Es Krim Ubi Jalar}

Menurut Padaga, M, dkk (2005), pada dasarnya kualitas es krim ditentukan oleh tekstur, rasa, bau, over run, dan kecepatan meleleh. Tabel 2 menyajikan hasil analisis organoleptik es krim ubi jalar, dengan atribut mutu organoleptik yang dinilai adalah warna, aroma, mouthfeel (tekstur di mulut), rasa, kecepatan meleleh, dan penampilan produk es krim secara umum.

Secara umum berdasarkan hasil analisis organoleptik, es krim dengan perlakuan perbandingan susu skim dan ubi jalar 7,5\%: $2,5 \%$ memiliki rata-rata skor hedonik terbaik dan tidak berbeda nyata dengan rata-rata skor hedonik perlakuan perbandingan susu skim dan ubi jalar 2,5\%: $7,5 \%$ dan kontrol.Rata-rata skor hedonik perlakuan perbandingan susu skim dan ubi jalar 7,5\% : 2,5\% tertinggi untuk atribut warna, aroma, mouthfeel, rasa, dan penampilan secara umum; namun tidak untuk kecepatan meleleh (Tabel 2).Sementara, secara umum rata-rata skor hedonik terendah adalah untuk perlakuan penggunaan $10 \%$ umbi ubi jalar, kecuali untuk atribut kecepatan meleleh yang skor hedoniknya tertinggi dibandingkan perlakuan lain. 
Tabel 2. Hasil Analisis Organoleptik (Uji Hedonik) Es Krim Ubi Jalar

\begin{tabular}{|l|c|c|c|c|c|}
\hline \multirow{2}{*}{$\begin{array}{c}\text { Atribut mutu } \\
\text { organoleptik }\end{array}$} & \multicolumn{5}{|c|}{ Skor Hedonik untuk Perlakuan } \\
\cline { 2 - 6 } & $\mathbf{8 1 0}$ & $\mathbf{6 7 5}$ & $\mathbf{3 0 5}$ & $\mathbf{7 2 5}$ & $\mathbf{4 0 0}$ \\
\hline \hline Warna & 3,69 & 4,81 & 5,00 & 6,31 & 6,19 \\
\hline Aroma & 4,38 & 4,93 & 4,69 & 5,56 & 5,19 \\
\hline Mouthfeel & 4,00 & 5,63 & 5,38 & 6,07 & 5,94 \\
\hline Rasa & 3,56 & 5,81 & 5,44 & 6,31 & 6,00 \\
\hline Kecepatan meleleh & 5,38 & 4,94 & 4,50 & 4,63 & 4,00 \\
\hline $\begin{array}{l}\text { Penampilan secara } \\
\text { umum }\end{array}$ & 3,44 & 5,73 & 5,06 & 6,25 & 5,88 \\
\hline Rata-rata & $4,07 \mathrm{c}$ & $5,31 \mathrm{ab}$ & $5,01 \mathrm{~b}$ & $5,85 \mathrm{a}$ & $5,53 \mathrm{ab}$ \\
\hline \hline
\end{tabular}

Keterangan :

Perbandingan padatan bukan lemak

$$
\begin{aligned}
& 810=\text { Susu Skim }: \text { Ubi Jalar }=0 \%: 10 \% \\
& 675=\text { Susu Skim }: \text { Ubi Jalar }=2,5 \%: 7,5 \% \\
& 305=\text { Susu Skim }: \text { Ubi Jalar }=5 \%: 5 \% \\
& 725=\text { Susu Skim }: \text { Ubi Jalar }=7,5 \%: 2,5 \% \\
& 400=\text { Susu Skim : Ubi Jalar }=10 \%: 0 \% \text { (Kontrol) }
\end{aligned}
$$

Penilaian hedonik panelis untuk atribut warna es krim bervariasi antara 3,69 sampai 6,19 (agak tidak suka sampai sangat suka), Rata-rata skor hedonik terendah diperoleh oleh perlakuan perbandingan susu skim dan ubi jalar $0 \%$ : $10 \%$. Rata-rata skor hedonik semakin meningkat dengan semakin berkurangnya konsentrasi umbi ubi jalar kukus yang digunakan sebagai pensubtitusi (Tabel 2). Warna umbi ubi jalar yang kuning-orange memang berpengaruh pada warna produk es krim, dimana semakin banyak konsentrasi penggunaan ubi jalar, warna es krim akan semakin kekuningan dan tampaknya hal ini kurang diminati oleh panelis, Warna es krim yang diminati adalah warna putih susu seperti perlakuan perbandingan susu skim dan ubi jalar $7,5 \%: 2,5 \%$ dan kontrol.
Rasa dalam es krim merupakan kombinasi cita rasa dan bau (aroma), yang diciptakan untuk memenuhi selera konsumen. Pada umumnya, rasa dan aroma es krim merupakan satu kesatuan yang saling menunjang karena hal pertama yang akan diperhatikan oleh konsumen saat membeli es krim adalah rasa dan aromanya, Dari hasil analisis organoleptik, tampak ada korelasi positif antara skor hedonik terhadap aroma dan skor hedonik terhadap rasa es krim ubi jalar yang diberikan oleh panelis, dimana peningkatan skor hedonik terhadap aroma diikuti pula dengan peningkatan skor hedonik terhadap rasa (Tabel 2). Semakin banyak konsentrasi subtitusi umbi ubi jalar kukus, semakin rendah skor penilaian panelis terhadap aroma dan rasa es krim ubi jalar. Tampaknya panelis tetap lebih menyukai es krim dengan 
cita rasa dan aroma susu yang masih terasa dibandingkan es krim dengan cita rasa dan aroma ubi jalar yang terlalu menonjol. Hal ini ditunjukkan dengan rata-rata skor penilaian hedonik panelis untuk es krim dengan perlakuan perbandingan susu skim dan ubi jalar 7,5\% : 2,5\% yang tertinggi, yaitu 5,56 (agak suka sampai suka) untuk aroma dan 6,31 ( suka sampai sangat suka) untuk rasa; dilanjutkan dengan rata-rata skor hedonik untuk aroma dan ras produk es krim kontrol yang padatan bukan lemaknya murni berasal dari susu skim (Tabel 2).

Menurut Padaga, M, dkk (2005), rasa sangat mempengaruhi kesukaan konsumen terhadap es krim, bahkan dapat dikatakan merupakan faktor penentu utama. Saat ini, rasa es krim di pasaran sudah sangat beragam sehingga diperlukan kejelian dan kreativitas untuk memadupadankan rasa yang menjadi kegemaran konsumen. Rasa es krim juga dipengaruhi oleh beberapa hal seperti bahan pengental yang dapat mengurangi rasa manis gula dan perubahan tekstur yang dapat mengubah cita rasa es krim.

Penilaian hedonik panelis untuk atribut mouthfeel (tekstur di mulut) bervariasi antara 4,0 sampai 6,07 (netral sampai sangat suka). Rata-rata skor hedonik tertinggi didapatkan oleh perlakuan perbandingan susu skim dan ubi jalar $7,5 \%: 2,5 \%$; sementara rata-rata skor hedonik terendah didapatkan oleh perlakuan es krim yang padatan bukan lemaknya murni berasal dari umbi ubi jalar kukus.

Tekstur es krim dipengaruhi oleh ukuran dari kristal es, globula lemak, gelembung udara, dan kristal laktosa (Suprayitno, E, dkk, 2001); sementara, menurut Padaga, M, dkk (2005), tekstur lembut es krim sangat dipengaruhi oleh komposisi ICM, cara mengolah, dan kondisi penyimpanan. Tekstur es krim yang baik adalah halus/ lembut (smooth), tidak keras, dan tampak mengkilap (Padaga, M, dkk, 2005); sementara, tekstur yang buruk adalah greasy (terasa ada gumpalan lemak), grainy (terasa seperti tepung), flaky/snowy (terasa ada serpihan es), lumpy/gelatin (seperti jelly), dan sandy (berpasir) (Suprayitno, E, dkk, 2001).

\section{Berdasarkan penilaian}

panelis terhadap atribut kecepatan meleleh didapatkan bahwa es krim dengan perlakuan perbandingan susu skim dan ubi jalar 7,5\%:2,5\% paling disukai karena tidak cepat meleleh pada suhu ruang. Subtitusi susu skim dengan umbi ubi jalar kukus tampaknya mempengaruhi kekentalan adonan es krim, dimana semakin tinggi konsentrasi penggunaan umbi ubi jalar kukus, semakin kental adonan es krim. Hal ini berpengaruh lanjut pada kecepatan meleleh es krim yang semakin lambat dan tekstur es krim yang cenderung menjadi keras.

Panelis menilai bahwa penampilan secara umum es krim dengan perlakuan susu skim dan ubi 
jalar $7,5 \%: 2,5 \%$ adalah terbaik dibandingkan perlakuan lainnya, termasuk kontrol, yaitu 6,25 (suka sampai sangat suka); sementara, es krim dengan perlakuan penggunaan ubi jalar $10 \%$ memperoleh rata-rata skor hedonik terendah, yaitu 3,44 (agak tidak suka sampai netral).

\section{Over Run dan Kecepatan Meleleh} Es Krim Ubi Jalar

Over run menunjukkan banyak sedikitnya udara yang terperangkap di dalam campuran es krim atau ICM karena proses agitasi. Over run mempengaruhi tekstur dan kepadatan yang sangat menentukan kualitas es krim. Adanya udara dalam ICM akan membentuk rongga-rongga udara yang akan segera terlepas bersamaan dengan melelehnya es krim. Semakin banyak rongga udara akan menyebabkan es krim cepat menyusut dan meleleh pada suhu ruang. Es krim yang berkualitas memiliki over run $70-80 \%$; sedangkan untuk industri rumah tangga 35-50\% (Padaga, M, dkk, 2004; Suprayitno, E, dkk, 2001). Tabel 3, Pengamatan Over Run dan Kecepatan Meleleh Es Krim Ubi Jalar

\begin{tabular}{|l|c|c|c|c|c|}
\hline \hline \multirow{2}{*}{ Variabel } & \multicolumn{5}{|c|}{ Perlakuan } \\
\cline { 2 - 6 } & $\mathbf{8 1 0}$ & $\mathbf{6 7 5}$ & $\mathbf{3 0 5}$ & $\mathbf{7 2 5}$ & $\mathbf{4 0 0}$ \\
\hline \hline Over run (\%) & 22,22 & 28,57 & 54,84 & 41,38 & 63,33 \\
\hline Kecepatan meleleh (menit) & 8,58 & 2,28 & 2,12 & 1,41 & 0,41 \\
\hline
\end{tabular}

Keterangan :

Perbandingan padatan bukan lemak

$$
\begin{aligned}
& 10=\text { Susu Skim }: \text { Ubi Jalar }=0 \%: 10 \% \\
& 75=\text { Susu Skim }: \text { Ubi Jalar }=2,5 \%: 7,5 \% \\
& 05=\text { Susu Skim }: \text { Ubi Jalar }=5 \%: 5 \% \\
& 25=\text { Susu Skim }: \text { Ubi Jalar }=7,5 \%: 2,5 \% \\
& 00=\text { Susu Skim }: \text { Ubi Jalar }=10 \%: 0 \%(\text { Kontrol })
\end{aligned}
$$


Peningkatan konsentrasi subtitusi susu skim dengan ubi jalar kukus tampaknya dapat meningkatkan kekentalan (viskositas) ICM sehingga semakin membatasi mobilitas molekul air karena ruang antar partikel di dalam ICM menjadi semakin sempit. Sempitnya ruang antar partikel menyebabkan udara yang masuk ke dalam ICM selama agitasi semakin sedikit sehingga nilai over run yang dihasilkan semakin rendah. Hal ini dapat dilihat dari hasil pengamatan over run pada Tabel 3, dimana dengan semakin banyaknya penggunaan umbi ubi jalar kukus sebagai pensubtitusi susu skim, nilai over run cenderung semakin rendah.Over run yang terlalu rendah dapat menyebabkan es krim beku menjadi produk yang terlalu keras dan lembek seperti puding; sementara over run yang terlalu tinggi menyebabkan es krim terlalu lunak, cepat meleleh, dan memiliki rasa yang hambar (Suprayitno, E, dkk, 2001),

Kecepatan meleleh es krim sangat dipengaruhi oleh bahan-bahan yang digunakan dalam pembuatan ICM, Es krim yang baik adalah es krim yang tahan terhadap pelelehan pada saat dihidangkan pada suhu ruang. Es krim yang cepat meleleh kurang disukai karena es krim akan segera mencair pada suhu ruang; namun juga perlu diperhatikan bahwa es krim yang lambat meleleh atau kecepatan melelehnya terlalu rendah juga tidak disukai oleh konsumen karena bentuk es krim yang tetap (tidak berubah) pada suhu ruang sehingga memberikan kesan terlalu banyak padatan yang digunakan (Padaga, M, dkk, 2005). Dari hasil pengamatan terhadap nilai over run dan kecepatan meleleh es krim ubi jalar, es krim dengan perlakuan perbandingan susu skim dan ubi jalar $7,5 \%$ : $2,5 \%$ menunjukkan mutu es krim yang baik.

\section{KESIMPULAN}

1. Subtitusi susu skim sebagai padatan bukan lemak dalam pembuatan es krim dengan ubi jalar kukus dapat diterima oleh panelis.

2. Perbedaan konsentrasi subtitusi susu skim dengan ubi jalar kukus berpengaruh terhadap mutu es krim.

3. Es krim yang dibuat dari susu skim dan ubi jalar kukus dengan perbandingan $3: 1 \quad(7,5 \%$ : $2,5 \%)$ menunjukkan mutu es krim yang baik. 


\section{DAFTAR PUSTAKA}

Hartoyo, T, 2004, Olahan dari Ubi Jalar, Trubus Agrisarana, Surabaya.

Padaga, M dan M, E, Sawitri, 2005, Es Krim yang Sehat, Trubus Agrisarana, Surabaya.

Rukmana, H, R, 2001, Aneka Keripik Umbi, Kanisisius, Yogyakarta.

Suprayitno, E, H, Kartikaningsih, dan S, Rahayu, 2001, Pembuatan Es Krim dengan Menggunakan Stabilisator Natrium Alginat dari Sargassum sp, Dalam Jurnal Makanan Tradisional Indonesia ISSN: 1410-8968, Vol, 1 No, 3, Hal, 23-27. 